\title{
Oscar Werner, S.J., and the Reform of Catholic Atlas Cartography in Germany (1884-88)
}

\author{
Peter H. Meurer \\ Independent Scholar \\ petermeurer@online.de
}

\begin{abstract}
The article describes a short but innovative chapter in the history of Catholic atlas making. The work was done by exiled German Jesuits in the Dutch houses after the expulsion of the Jesuits in 1872 during the Kulturkampf. The project began in 1880-81 with four maps of China and India in the Catholic journal Die katholischen Missionen by Alexander Baumgartner, S.J. (1841-1910). His work was taken over by Oscar Werner, S.J. (1849-?). Werner's Katholischer Missions-Atlas (1884) was the first Catholic missionary atlas. Its twenty-seven maps covered the worldwide dioceses subject to the Propaganda Fide. The supplementary Katholischer Kirchen-Atlas (1888) included fourteen maps of lands with an established Catholic hierarchy. Published in a large number of copies for a low price, both atlases helped to popularize Catholic cartography. This Jesuit groundwork abruptly ended when Werner resigned from the Society in 1891 . The German tradition in Catholic atlas cartography was then taken over by members of Society of Divine Word, beginning with the Katholischer Missionsatlas (1906) by Karl Streit SVD (1874-1935) and continuing for over a century with the Atlas hierarchicus (1913-2011).
\end{abstract}

\section{Keywords}

Catholic atlases - Jesuit cartography - Oscar Werner - Germany - Kulturkampf Alexander Baumgartner - Society of the Divine Word (svD) 
The origins of ecclesiastical atlas cartography are purely Catholic. The genre emerged in the middle of the seventeenth century in the form of several atlases by particular orders. ${ }^{1}$ The first atlas of the entire world church was the Geographia hierarchica (1703) with twenty-one maps. ${ }^{2}$ It appeared as volume two of the Atlas novus (1702-1710) by the Jesuit Heinrich Scherer (1628-1704), a teacher at the Jesuit University of Dillingen and the prince's educator at the Bavarian court. ${ }^{3}$ This Catholic atlas making stagnated over the next century and a half. A new milestone was the monumental and challenging work L'orbe cattolico (Rome, 1858-59), consisting of three text volumes and an atlas with 145 diocesan maps. The author of this quasi-official publication was Girolamo Petri (1806-71), who worked at the papal Segretaria di Stato. ${ }^{4}$ The unification of Germany in 1871 and the expulsion of Jesuits in 1872 during the Kulturkampf (c.1871-80) brought about a new phase in atlas making, as German Jesuits in exile tried to situate themselves and find new directions for their work.

In particular, the German Jesuit Oscar Werner's two-part Catholic atlas project pioneered a completely new approach. The Katholischer Missions-Atlas (1884) was the first Catholic missionary atlas. It shows the Catholic areas of the world subjected to the Propaganda Fide. The supplementary Katholischer Kirchen-Atlas (1888) included the lands with an established Catholic hierarchy. Issued in close connection with the popular journal Die katholischen Missionen, the low-priced atlases were published for a wider audience. This makes them important elements of the popularization of Catholic cartography. Yet, Werner's atlases remained an isolated project, without integration in any other efforts of contemporary Jesuit science. He completed them in difficult times, in the Dutch exile of the German Province of the Society.

1 Giovanni de Montecalerio, OFMCap, ed., Chrorographica descriptio Provinciarum et Conventuum Fratrum Minorum S. Francisci Capucinorum (Rome: n.p., 1643), five more editions until 1713. Augustin Lubin osA, Chorographia Augustiniana, sive conventuum ordinis Eremitarum Sancti Augustini per provincias nec non eorundem topographica descriptio (Paris: Pierre Bauduyn, 1659).

2 Geographica hierarchica, sive status ecclesiastici Romano-catholici per orbem universum distributi succinta descriptio historico-geographica (Dillingen, Bencard; Munich: Rauch, 1703).

3 Scherer awaits an in-depth study. For a short biography see Johannes Dörflinger, "Heinrich Scherer," in Neue Deutsche Biographie (Berlin: Duncker \& Humblot, 2005), 22:690-91.

4 Girolamo Petri, L'orbe cattolico ossia Atlante geographico storico ecclesiastico (Rome: Tipografia della reverenda Camera Cattolica, 1858-59), 3 vols., and atlas. 


\section{The Situation around 1880}

New developments in Christian atlas cartography began in the second quarter of nineteenth century initially as a Protestant domain. In absence of orders and worldwide hierarchy, it attempted to illustrate the working areas of the various missionary societies. The beginnings of this subgroup of missionary cartography appeared in the English-speaking world. Early missionary atlases were edited by private publishers, in 1839 by James Wyld (1812-87) in London and in 1848 by Sidney Edward Morse (1795-1871) for the subscribers of his New York Observer. ${ }^{5}$ From 1848 volumes of the Colonial Church Atlas appeared, showing the Anglican dioceses outside Great Britain. ${ }^{6}$ From 1857 , however, the standard work, reissued many times, was the atlas of the Church Missionary Society.

German-language areas, fragmented both politically and religiously, became the second early center of Protestant atlas cartography. Missionary societies published atlases largely for their members and benefactors as a way of illustrating the lands where their overseas efforts were concentrated. The Moravian Church (from 1852), the Rhenish Mission Society (from 1853), and the Basel Mission (from 1857) all produced atlases. ${ }^{8}$ A seminal figure in German Protestant atlas making was the pastor and mission writer Reinhold Grundemann (1836-1924). ${ }^{9}$ His magnum opus was the scholarly Allgemeine MissionsAtlas (1867-71) in four sections with seventy-two annotated maps, developed in cooperation with the leading German map house Perthes in Gotha. ${ }^{10}$ The

5 James Wyld, Atlas of the Different Parts of the World Designed to Show the Stations of the Protestant Missionaries (London: James Wyld, 1839); Sidney Edward Morse, Cerographic Missionary Atlas (New York: Morse, 1848).

6 The Colonial Church Atlas Arranged in Dioceses (London: Society for the Propagation of the Gospel in Foreign Parts, 1842-).

7 Church Missionary Society, The Church Missionary Atlas, containing Maps of the Various Spheres of the Church Missionary Society (London: Church Missionary House, 1857-).

8 The Moravian atlases are Lucas Linder, Kärtchen und Statistik von Missionsgebieten der Brüdergemeinde (Bautzen: Monse, 1852) and Levin Theodor Reichel, Missions-Atlas der Brüder-Unität (Herrnhut: Missions-Verwaltung, 186o). For the Rhenish Mission, Johann Christoph Wallmann, Atlas der Rheinischen Missions-Gesellschaft übersichtlich und speziell die Gebiete darstellend, auf welchen die Gesellschaft tätig ist (Barmen: Rheinische Missionsgesellschaft, 1853). For Basel, Joseph Friedrich Josenhans, Atlas der evangelischen Missionsgesellschaft zu Basel (Basel: Comptoir der evangelischen Missions-Gesellschaft, 1857).

$9 \quad$ For a short biography see Hans Bardtke, "Reinhold Grundemann," in Neue Deutsche Biographie (Berlin: Duncker \& Humblot, 1966), 7:221-22. Grundemann's later works include some popular smaller atlases on German Protestant mission.

Allgemeiner Missions-Atlas nach Originalquellen (Gotha: Perthes, 1867-71). 
publishers wanted an interconfessional atlas that could sell to broader audiences, but the result clearly shows Grundemann's Protestant background.

Catholic life in Central Europe recovered slowly after the decline of structures and organization in the Napoleonic era. German-speaking Jesuits could live after the restoration of the Society in 1814 only in Austria-Hungary in longer-term continuity. In Switzerland, the Society was definitively banned in 1848 by the federal constitution. The climax of a new flourishing in Germany was the 1863 founding of a Collegium Maximum in the former Benedictine abbey Maria Laach in the Rhineland. But this period of reestablishment was abruptly interrupted by the German Kulturkampf and specifically the Jesuit Law of July 4, 1872. All institutions and activities of the Jesuits in the territory of the Reich were dissolved and forbidden.

Due to family relationships and other personal patronage contacts, the Society quickly received support from the aristocracy in neighboring countries in the west. The influential journal Stimmen aus Maria Laach (founded in 1865, today: Stimmen der Zeit) with its editorial staff centered around Rudolf Cornely, S.J. (1830-1908), first took refuge in the castle of the German-born Countess Marie Amelie de Robiano (1807-80) in Tervuren near Brussels. The scholasticate and tertianship found a home in two English houses provided by Lady Mary Stapleton-Bretherton (1809-83), Ditton-Hall in Cheshire and Portico near Liverpool. Juniorate, novitiate and writer's homes were harbored in some castles and manors in the Dutch Province of Limburg, including Bleijenbeek near Afferden provided by Franz Egon Graf von Hoensbroech (1805-74), Exaten near Baexem, bought by the Society from Theodoor Graaf De Geloes d'Elsloo (1816-93) and Wijnandsrade near Nuth opened by Ludwig Freiherr von dem Bongart (1819-78). All these temporary homes merged in 1893 into the new Collegium Maximum of the exiled German Province in Valkenburg. ${ }^{11}$ Finally, in 1899, the central writer's home of Bellevue in Luxemburg was founded.

\section{Five Maps in the Journal Die Katholischen Missionen}

The beginnings of Catholic missionary cartography in Germany are linked with the monthly periodical Die Katholischen Missionen, published with changing subtitles until 1998. It was founded in 1873 as the official high-circulation magazine of the Verein zur Glaubensverbreitung, the strongest German union

11 "The New Scholasticate of the German Province, St. Ignatius College, Valkenberg," Woodstock Letters, 25, no. 1 (February 1, 1896), 119-23. 
for the financial and ideational support of Catholic missionaries. ${ }^{12}$ It informed sponsors and mostly non-academic members about the exotic geography and ethnography of the mission areas. The journal and association were subsidiaries of the influential French Oeuvre de la Propagation de la Foi (founded in 1822), which had its own weekly magazine, Les Missions catholiques (Lyon, 1868-). Issues of Die Katholischen Missionen-like the Stimmen aus MariaLaach and many other works of the German Jesuits - were published by the leading Catholic house Herder in Freiburg im Breisgau. According to the imprint, the Herder manager Franz-Josef Hutter (1840-85) edited the journal, "in cooperation with some members of Society of Jesus." The founding editor and most productive author in the early years was likewise Rudolf Cornely.

From 1872, the French weekly Missions catholiques had already included singular maps in the text, and from 1877 , yearly loose inserts of larger-format colored maps also appeared. Following this model, from 1875, Die Katholischen Missionen had cartographical illustrations in black and white for some articles, as well as five full-page color maps $(18.5 \times 24.5 \mathrm{~cm})$ between 1879 and 1881:

- Issue 12/1879: "Die katholischen Missionen Süd-Africa's," in the article, "Die Missionsgebiete Süd-Afrika's” (250-52).

- Issue 1/1880: "Die apostolischen Vicariate von Vorderindien," in the article "Die apostolischen Vikariate von Vorderindien" (7-11).

- Issue 5/1880: "Kirchliche Eintheilung von Hinterindien," in the article "Die kirchliche Eintheilung von Hinterindien" (89-92).

- Issue 6/1881: "Die Apostolischen Vicariate China's, westlicher Theil” and "Apostolischen Vicariate China's, östlicher Theil," two maps, in the article "Die Apostolischen Vicariate China's" (113-18).

The maps were two-color lithographs printed using three plates. The topographical outlines correspond to the standards of contemporary atlas maps. Particular additions were the boundaries of the apostolic vicariates and the entries of the major Catholic mission stations from primary sources. In all, the maps seem somewhat hastily designed. A lack of coherence is sometimes evident between the contents of the maps and the accompanying texts. As usual in Die Katholischen Missionen and probably in consequence of the Jesuit

12 This "Society for the Propagation of the Faith" was an informal union of three subgroups founded in the German-speaking lands: the Leopoldinen-Stiftung (Austria, 1829), the Ludwig-Missionsverein (Bavaria, 1839) and the Franziskus-Xaverius-Verein (rest of Germany, 1834). They were merged in 1922 into the newly founded Päpstliches Werk der Glaubensverbreitung, the German branch of the Opus Pontificum a Propagatione Fidei. 


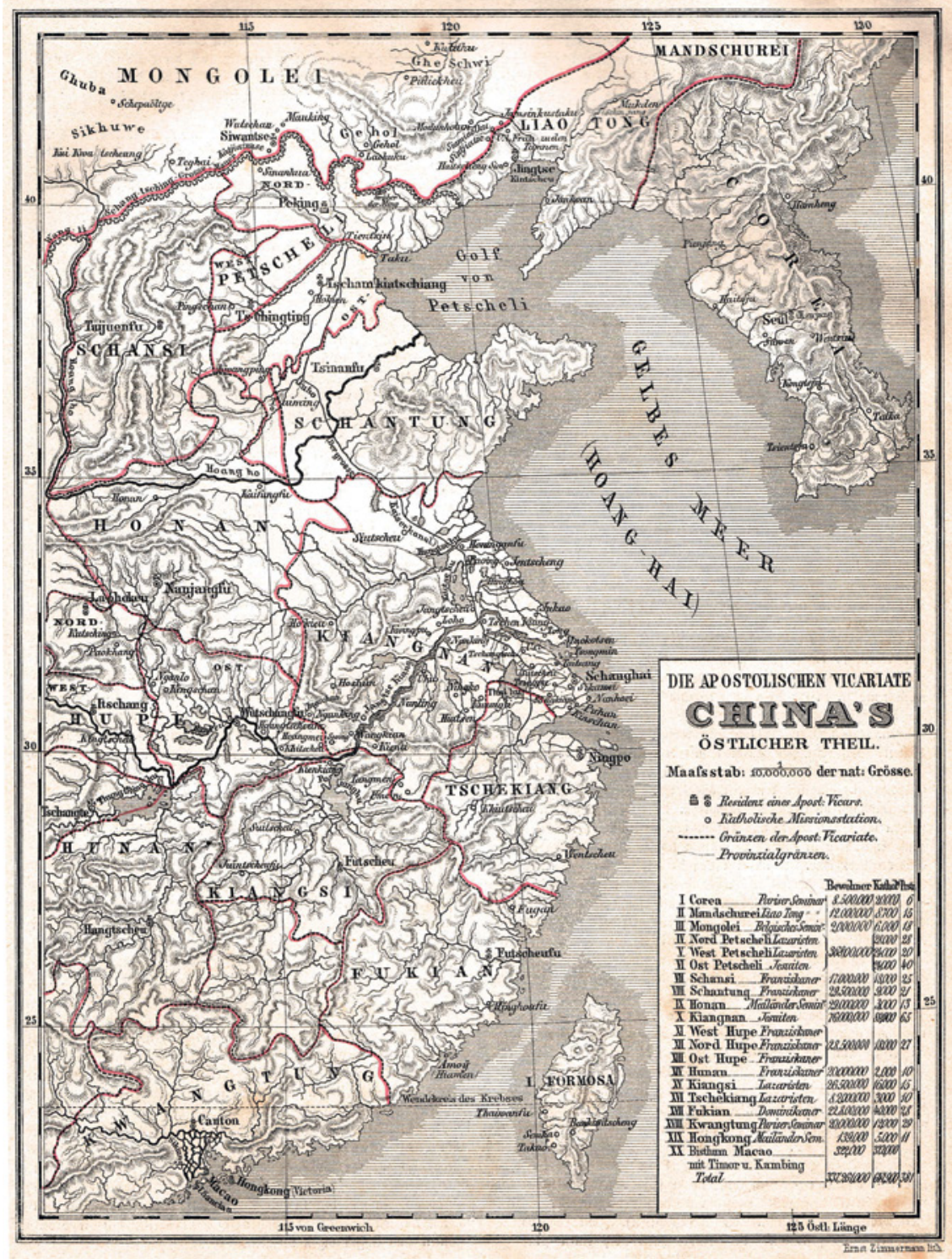

FIGURE 8.1 Alexander Baumgartner, "Die Apostolischen Vicariate China's, östlicher Theil," Die Katholischen Missionen 6 (1881)

Law, author signatures are missing. The maps are signed only by the local lithographers Victor Baumann and Ernst Zimmermann. However, Alexander Baumgartner's (1841-1910) authorship is clear from a note in the introduction of the Katholischer Missionsatlas (see below) in 1884, "Even earlier the Reverend Father Alexander Baumgartner, S.J. drafted maps of East India and China 
which were published in the years 1881 and 1882 in "Die Katholischen Missionen" (Figure 8.1).

\section{Alexander Baumgartner, S.J.}

Alexander Baumgartner was born on July 27, 1841 in St. Gallen, the oldest son of the Swiss Catholic-liberal politician Gallus Jakob Baumgartner (1797-1869).13 He attended the abbey school in Einsiedeln, Switzerland and from 1859 the Jesuit Gymnasium in Feldkirch, Austria-Hungary on the Swiss border. On June 27, 186o Baumgartner entered the Society in the monastery of Gorheim, in the Hohenzollern Land that had recently come under the administration of Prussia just north of the Bodensee. He received further education in Feldkirch, Friedrichsburg near Münster, and at the intellectual center of Maria Laach Abbey. Between 1867 and 1869 he worked as a teacher of modern languages and natural sciences in Feldkirch. Baumgartner was ordained in Germany on July 30, 1872, but after the Jesuit Law, he left for England. He completed the tertianship in Ditton Hall and worked briefly as a teacher of modern languages at the renowned Stonyhurst College in Lancashire. Baumgartner's first station after his return to the continent in 1875 was Tervuren in Belgium. He became a member of the editorial boards of the Stimmen aus Maria-Laach and Die Katholischen Missionen. He also started a career as prolific writer in literary history. Among many projects was a basic biography of Johann Wolfgang von Goethe (17491832), published from $1879 \cdot{ }^{14}$ Later Baumgartner traveled extensively and lived in the Jesuit houses in Bleijenbeek (1880-85) and Exaten (1886-99). In 1897, the publication of a multi-volume history of world literature began. ${ }^{15}$ In 1899, Baumgartner moved to the new writer's home Bellevue in Luxemburg, where he died on September 5, 1910.

The entry of Baumgartner into mapmaking may have been purely coincidental. The editorial labor around Die Katholischen Missionen was divided,

13 Biographical information comes from two obituaries: Qtto Pfülf in Stimmen aus Maria Laach 79 (1910): 349-72; Niklaus Scheid, P. Alexander Baumgartner S.J. Ein Gedenkblatt seines Lebens und Wirkens, Frankfurter zeitgemäße Broschüren, N.F. 31,2 (Hamm: Breer \& Thiemann, 1912).

14 The first volumes were published from 1878 by Herder in a series of supplements to the Stimmen aus Maria-Laach. The first complete edition was: Goethe: Sein Leben und seine Werke, 3 vols. (Freiburg: Herder, 1885-86).

15 Geschichte der Weltliteratur (Freiburg: Herder, 1897-1912). Five volumes appeared during Baumgartner's lifetime and two posthumously. Three more volumes remained unpublished. 
with Baumgartner having responsibility for Asia. When he wrote summary articles about the ecclesiastical subdivisions of India and China, he may have seen the need to add illustrating maps. As there was no skilled cartographer working with the journal, he took over this work himself. Baumgartner's skills and interests in the field had developed in an earlier publication. In 1883, he made a grand tour through the "Nordic mission countries" from Denmark over Scotland to Iceland, Scandinavia and the Baltic parts of Russia. Upon his return, he published Nordische Fahrten (1889-), a masterpiece of travel writing. It combined descriptions of geographical and ethnographic features with deep treatises on religion and literary history. The three volumes were also richly illustrated, including some panoramas, views and sketch maps from Baumgartner's own hand. ${ }^{16}$

Regarding his four maps in Die Katholischen Missionen, Baumgartner recognized the limited possibilities inherent to his situation. Nevertheless he had larger ambitions. In a footnote to the text on the Indian subcontinent he wrote:

We intend by no means to provide a complete mission map, but only a map of the present ecclesiastical subdivision. We hope to comply gradually and later pursue the legitimate wish for more exact maps of singular mission areas.

Other duties and interests made Baumgartner's active role in this subject an intermezzo. But he passed on the idea to a Jesuit brother, Oscar Werner.

\section{Oscar Werner, S.J.: Fragments of a Biography}

Oscar Werner was born on April 8, 1849 in Bierna near Zawidów in Lower Silesia, at that time part of Prussia. ${ }^{17} \mathrm{He}$ attended the Elisabeth Gymnasium in Wrocław, the vocational school in Świdnica and the Gewerbeakademie in Berlin. At the age of twenty-one Werner entered the Society of Jesus on

16 Alexander Baumgartner, Nordische Fahrten: Skizzen und Studien (Freiburg: Herder, 188995), a series with three volumes: Island und die Färöer 1 (1889); Durch Skandinavien nach St. Petersburg 2 (1890); Reisebilder aus Schottland 3 (1895).

17 There is no historical literature on Oscar Werner. The following biography is based on material in the Archiv der Deutschen Provinz der Jesuiten, Munich: personal file on Werner (Abt. 48-1, J 8, Nr.66); annual catalogues of the German Jesuit province (Abt. 6o Ja). I express my deep gratitude to the archivist Dr. Clemens Brodkorb for his support of my research. 
March 7, 1871 and completed his novitiate in Friedrichsburg. He continued his studies after the expulsion in the Netherlands, first in Wijnandsrade (1872-73) and Bleijenbeek (1873-77), where he was also deployed as librarian and teacher of mathematics. In 1877, he began the scholasticate in Ditton Hall and was ordained on September 7, 1879 in the cathedral of Liverpool.

Elected for a writer's career, Werner received his first scholarship from 1880 to 1882 at the Collegium Romanum in Rome. Subsequently, he completed the tertianship in Portico (1882-83). From 1883 to 1885 Werner returned to Bleijenbeek and from 1885 to 1887 in Exaten, where he finished his Missions-Atlas.

There is a single piece of evidence for Werner's cartographic expertise beyond his own atlases. Around 1886 he drew a map of the Jesuit schools in Germany as they existed in $1725 \cdot{ }^{18}$ It was made to illustrate an edition of sources on the Jesuit education system in Germany, compiled in Exaten by Georg Michael Pachtler, S.J. (1825-89). In 1887, Werner stayed at the Collegium Romanum a second time, where he signed the foreword of his completed Kirchen-Atlas. But the main result of his studies in Roman archives and papal offices was the condensed vademecum Orbis terrarum catholicus, a hierarchically structured description of all Catholic dioceses in the world with extensive historical and actual statistical data. ${ }^{19}$

The final years of Werner's biography remain unclear. The annual reports of the German Jesuits from 1889 to 1891 still register him under the house at Exaten. But the foreword of the Orbis terrarum catholicus for May 4, 1890 is subtitled, "in castello Raeckelwitz." Räckelwitz Castle in German Upper Lusatia was in the possession of the Catholic Counts of Stolberg-Stolberg. Werner served as chaplain of the private St. Mary's Chapel in 1890 and $1891 .^{20}$ On August 1, 1891 Oscar Werner resigned from the Society. The further course of his life is difficult to trace. He authored no new works.

18 "Karte der Unterrichts- und Erziehungsanstalten der Deutschen Assistenz S.J., im Jahre 1725, nach Quellen bearbeitet und gezeichnet von O. Werner S.J.," Georg Michael Pachtler, Ratio studiorum et institutions scolasticae Societatis Jesu per Germaniam 2, G. M. Pachtler, ed., Monumenta Germaniae Paedagogica 5 , Karl Kehrbach, ed. (Berlin: A. Hofmann, 1887), facing 524, 26.5 x $18.5 \mathrm{~cm}$. https://archive.org/details/ratiostudiorumeto5jesu, accessed June 12, 2018. The map also appears in volume three.

19 Orbis terrarum catholicus, sive totius ecclesiae catholicae et occidentis et orientis conspectus geographicus et statisticus. Elucubratus per O. Werner S. J. ex relationibus ad Sacras Congregationes Romanas missis et aliis notitiis observationibusque fide dignis (Freiburg: Herder, 1890).

20 Information kindly provided by Dr. Birgit Mitzscherlich (Diözesanarchiv DresdenMeißen, Bautzen). 


\section{Werner's Katholischer Missions-Atlas (1884)}

In 1884, Herder in Freiburg published the first edition of the Katholischer Missions-Atlas. ${ }^{21}$ According to the very short and undated foreword, Werner had collected the data during his first sojourn in Rome. He expressed his thanks to Cardinal Giovanni Simeoni (1816-92) and Giovanni Maria Zonghi (1847-1941), the prefect and the secretary of the Propaganda Fide. Werner makes reference to the roots of the project, the four maps of India and China completed by Alexander Baumgartner in Die Katholischen Missionen. He then refers to the "thousands of brave and joyful Apostles who had crossed the seas to follow the Great Commission" (Matthew 28:19) of Jesus, continuing,

The journal Die Katholischen Missionen endeavors to describe the life, work and suffering of these heralds of the faith. To complement this, the present missionary atlas is intended to show the settings of their activity to the readers.

The issue of May 1884 of Die Katholischen Missionen included a leaflet with a proof map (no. 18, Oceania) and an invitation for subscriptions to the readers of the journal. The subscription price until August 1884 was three marks for paperback or four marks for half cloth. By comparison, the average daily wage of an industrial worker in Germany at that time was around two marks.

The Missions-Atlas consists of nineteen sheets that comprised a total of twenty-seven maps. A helpful and innovative addition were three stemmata on the complex development of the ecclesiastical subdivisions in AustraliaPolynesia, India-China, and Canada-USA. The four maps of India and China (nos. 6-9) are printed from the same plates as in the 1880-81 edition. These and the other maps now have a full colour printed from five more plates. They were lithographed and printed by the "chemigraphical establishment" of $\mathrm{Ru}-$ dolf Loes in Leipzig (fl. 1875-1919).

Werner's Missions-Atlas is the first special Catholic missionary atlas. Remarkable is his definition of this new genre according to canon law. He conceived of the atlas as a collection of maps covering worldwide the ecclesiastical territories subjected to the Propaganda Fide. This explains, for instance, the inclusion of maps of the Apostolic Vicariates in Scandinavia (no. 2) and in the Balkan lands and Near East with the Oriental Catholic Churches (nos. 3-4). On the other hand, the British Isles with their newly established ecclesiastical

21 Katholischer Missions-Atlas: Neunzehn Karten in Farbendruck mit begleitendem Text von O. Werner, S.J. (Freiburg: Herder, 1884). 
hierarchy do not appear. ${ }^{22}$ The natural focus of the Missions-Atlas with fourteen maps lies in the structure of the Catholic Church in the non-European world. The depiction of the American continent is of particular interest. Werner provides a general map of today's Canada (Figure 8.2) and an additional three-part map on a larger scale of the region from Lake Huron to the east coast (no. 13) with its long Jesuit missionary tradition. There is no general map of the complex contemporary ecclesiastical situation in South America, which was not subjected to the Propaganda Fide. But Werner here gives two historical maps of the Jesuit mission in the eighteenth century in what became Colombia-Ecuador-Peru (no. 16) and Paraguay (no. 17). Nevertheless, Werner gave a complete and detailed mapping of the boundaries and residences of ecclesiastical provinces, dioceses, apostolic vicariates and prefectures. He also tried to make note of the major Catholic missionary stations, although due to size and scale, this had to be done with some generalization.

\section{The Second Edition of Missions-Atlas (1885)}

Interest and economic viability resulted a second issue of Werner's MissionsAtlas by Herder after July of $1885 .{ }^{23}$ Werner's introductory text was newly written and enlarged by statistical data. The four maps of India and China were replaced by new and reworked versions, with revisions elsewhere.

Possibly the most interesting detail of this second edition is a passage in the newly written foreword composed in Bleijenbeek. Werner praises the "beauty" of the Catholic Church with its 217 million members, with its diversity of origins, languages and traditions, but with its unity in faith, sacraments and aim. Then he continues:

The visual depiction of this beauty would be a worthy task of a church atlas: an atlas reflecting the entire hierarchical outline of the Church and the distribution of the Catholics in various ecclesiastical provinces, dioceses, apostolic vicariates and prefectures, in parishes and districts. [This is] an enormous task, which will exceed the strengths and means of an individual.

22 The Catholic hierarchy was restored in England (1850) and Scotland (1878). But the countries still remained in the late nineteenth century under the Propaganda Fide.

23 Katholischer Missions-Atlas... von O. Werner, S.J., 2nd ed. (Freiburg: Herder, 1885). 


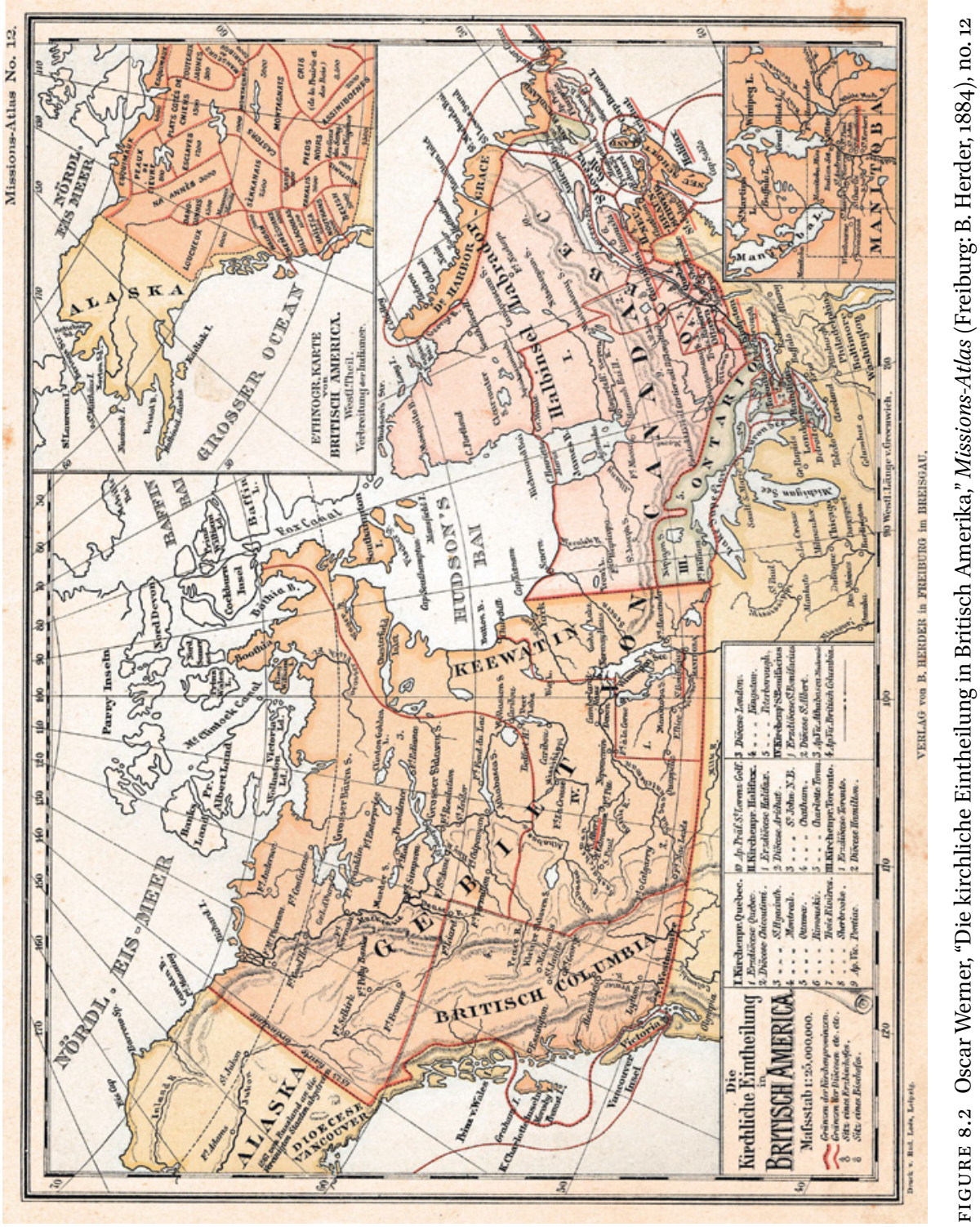


This appeal for collaborative progress is emphatic, but it remained largely a dream given the circumstances in the Netherlands and the Jesuit order as a whole.

\section{The French Editions of the Atlas des missions catholiques (1886)}

Some collaborative help did come for the French edition. In 1886 Herder issued a translation of Werner's atlas in Lyon, Atlas des missions catholiques with twenty maps under the imprint "Oeuvre de la Propagation de la Foi." ${ }^{24}$ A new foreword began by describing the growing collection of missionary maps resulting from the annual supplements to the Missions catholiques. At some time in future, these should be used to form a basic missionary atlas. ${ }^{25}$ But to please the "pious impatience of the friends of mission," the present publication was adopted from the original of the German subsidiary being an "atlas of invaluable importance and precision." The target group, mentioned in the foreword, were the subscribers of the Missions catholiques.

The editor and translator of the French edition was Valérien Groffier (1852-1929). ${ }^{26}$ Two of his brothers were members of the Society of Jesus, although Groffier himself broke off a novitiate in a Trappist monastery and spent another probation in the French army. In 1876, he joined the service of the Oeuvre de la Propagation de la Foi. He acted for over forty years as editor of the Missions catholiques. Evidence of Groffier's skill in religious cartography is a religious world map (Paris, 1882) with exhaustive tables on interconfessional Christian missions. ${ }^{27}$ From 1892, he also taught geography at the commercial college in Lyon.

The text is translated with only minor additions, notably the French missions in Africa, from the second German edition. The maps are printed from

24 Atlas des missions catholiques: Vingt cartes teintées, avec texte explicatif par le R. P. O. Werner, de la Compagnie des Jésus; Traduit de l'Allemand par M. Valérien Groffier... (Lyon: Bureaux des Missions Catholiques, 1886).

25 This aim was never realized. In connection with the French Propagation de la Foi appeared André Boucher's Petit atlas des missions catholiques (Paris: Hattier, 1928), which only included three folded maps. The first real atlas of the society was Joseph Despont, ed., Nouvel atlas des missions (Paris and Lyon: Oeuvre de la Propagation des la Foi, 1951) with nineteen maps.

26 For a biography see the obituary in: Les Missions catholiques 61 (1929): 536A-536B.

27 Valérien Groffier, "Planisphère des croyances religieuses et des missions chrétiennes" (Paris: Imprimerie Robelin, 1882), 127 x 89 cm. http://gallica.bnf.fr/ark:/12148/btvib53022 949m, accessed June 12, 2018. 
the same plates but with a new plate in black for names and inscriptions now in French. Three new maps were added: a world map showing the propagation of the Catholic faith between the founding of the Oeuvre de la Propagation de la Fo $i$ in 1822 and 1885 and two maps of the ecclesiastical structures in England-Scotland and Ireland, the latter correcting the limited amount of data in Werner's original. In return, Werner's two historical maps on the Jesuit missions in South America were omitted. Herder also published a parallel French edition with their own imprint. Groffier was still named as the editor but all references to the Oeuvre de la Propagation de la Foi are missing.

\section{Werner's Katholischer Kirchen-Atlas (1888)}

In 1888, Herder published as a complementary volume the Katholischer KirchenAtlas by Oscar Werner. Any relation to the journal Die Katholischen Missionen is no longer mentioned. The short foreword describes the aim as "to visualize in a few maps the entire setting of the Church Militant." ${ }^{28}$ The fourteen maps (average format $18.5 \times 24 \mathrm{~cm}$ ) show the regions with non-missionary hierarchies under the Holy See which were not covered in the Katholischer Missions-Atlas: Italy, Spain and Portugal, France, Belgium, and the Netherlands, Germany with Switzerland, the Catholic population in Germany and Switzerland, AustroHungary, the Catholic population in Austro-Hungary, England and Scotland, Ireland, Russia and Poland, Central America, and South America.

The introductory "General map of the ecclesiastical structuring of the world" (no. 1) reflects the canonical complexity. The coloring makes a distinction between "countries with ordinary hierarchical organization" and four different forms of subjection under the Propaganda Fide for missionary areas. Clear distinctions were not always easy in this regard, and some of Werner's decisions for inclusion in this Kirchen-Atlas are open to discussion. For example, this part of his atlas project has the maps of England-Scotland and Ireland (nos. 10 and 11) with the recently restored ecclesiastical hierarchy, but the general map shows the British Isles as subjected to the Propaganda Fide as they technically still were. A complex border case is the map of Germany (Figure 8.3). Within the territory of the new German Reich existed not only normal archdioceses and dioceses but also exempt dioceses and apostolic vicariates and prefectures. This may be seen as an effort to orient the Kirchen-Atlas to its German-speaking readership and their complex sense of Catholic identity. Further evidence come from the dual maps of Germany-Switzerland (nos. 6 and 7)

28 Oscar Werner, Katholischer Kirchen-Atlas (Freiburg im Breisgau: Herder, 1888). 


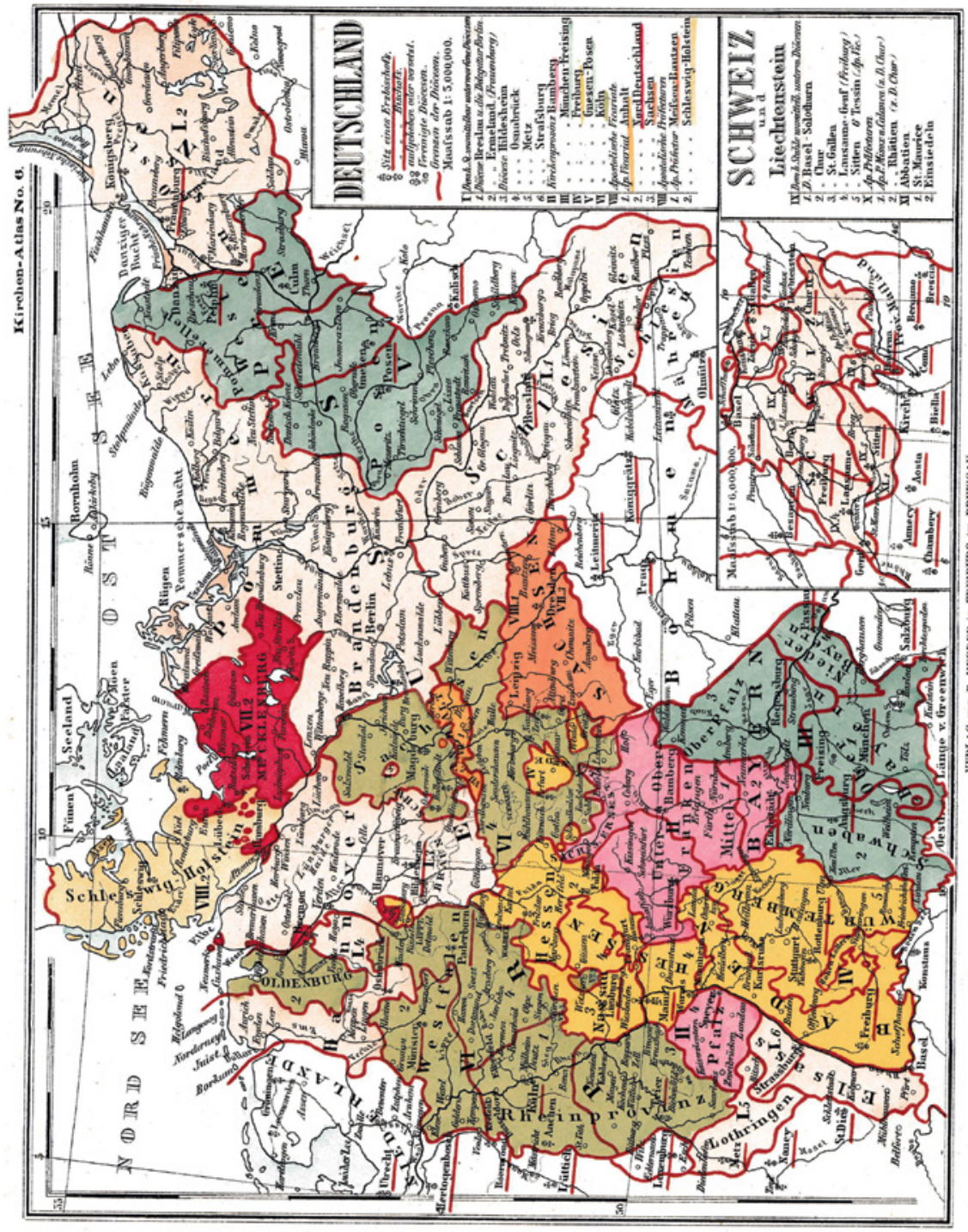

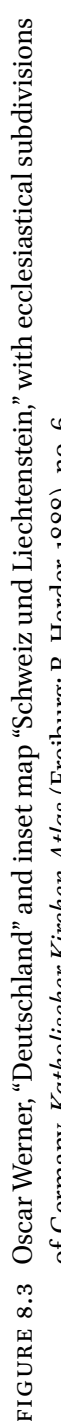


and Austria-Hungary (nos 8 and 9), in which one shows the ecclesiastical subdivision and the other the distribution of the Catholic population.

As with the the Missions-Atlas, the maps in the Kirchen-Atlas are again colour lithographs printed from up to seven plates. The lithographer and printer are not named, but the maps themselves are of high quality and clarity. Ecclesiastical provinces are indicated by a uniform colouring. The boundaries of the related dioceses are marked by red lines. Seats of archbishops and bishops are highlighted by symbols and underlining in red. Other symbols show dissolved seats and some towns of secular importance.

The text section gives, with varying levels of completion, detailed statistical data for each diocese. Werner here used the material that later appeared more exhaustively in his 1890 Orbis terrarum catholicus. An appendix (Anhang) gives a list of the hierarchical subdivisions in those regions that were treated in the Missions-Atlas. A general index includes the names of all ecclesiastical districts in both atlases.

\section{Balance and Outlook}

Werner's Katholischer Missions-Atlas and Katholischer Kirchen-Atlas generated positive echos in the contemporary academic world, actively cited for more than two decades. Nevertheless, they were published for a wide audience and a low price, with a large circulation and in the vernacular language. This makes Werner a pioneer in the popularization of Catholic cartography in the age of mass industrial printing. But in the end, the big plans in missionary cartography formulated by himself and Baumgartner remained a distant ideal. After the Kirchen-Atlas, Werner also retreated from the field.

In principle, this new beginning around Oscar Werner could have been continued by others within the Jesuit order. A suitable candidate was Louis Carrez, S.J. $\left(1833^{-1920)}{ }^{29}\right.$ He had joined the Society in 1851 . From 1869 , he taught history at the Jesuit College Saint-Clément in Metz. This Lorraine town was ceded to Germany in 1871, and Carrez was thus affected by the expulsion after the Jesuit Law in 1872. He returned to his hometown Châlons-sur-Marne in Champagne, where he lived as an independent author in a Jesuit community. His publications since the 1880 os include some school atlases. ${ }^{30}$ In 1900, his

29 Louis Carrez merits a separate study. See Louis Viansson-Ponté, Les jésuites à Metz (Strasbourg: Le Roux, 1897).

$30 \quad$ Atlas général de géographie, contenant vingt-quatre cartes coloriées et un texte explicatif en regard; Atlas de géographie ancienne; Petit Atlas de géographie... à l'usage des classes 
groundbreaking Atlas geographicus Societatis Jesu with forty-five annotated maps appeared. ${ }^{31}$ But Carrez likewise abandoned his cartographic work after he published his atlas. His later publications consisted of historical studies. In general, atlas cartography played a subordinate role in Jesuit science in Europe in the early twentieth century. An isolated example is the atlas of the Catholic missions in the Dutch colonies by Jean Chrétien Joseph Kleijntjens, S.J. (18761950), which appeared in $1928 .{ }^{32}$

The short Jesuit tradition in the publication of Catholic world atlases was instead taken over by the Society of the Divine Word (Societas Verbi Divini, SVD), the first German Catholic missionary congregation. It was founded during the Kulturkampf in 1875 in Dutch exile in Steyl by Arnold Janssen (18371909, canonized in 2003), a pioneer of the press apostolate. Short after 1900 the SVD increased its scientific and publishing work in direct competition with the Jesuit group around Die Katholischen Missionen. The central figure of their cartographical activities was Karl Streit, SVD (1874-1935). ${ }^{33}$ His Katholischer Missionsatlas (1906) followed the footsteps of Oscar Werner. ${ }^{34}$ At the suggestion of the Roman Curia, the first edition of Streit's epoch-making Atlas Hierarchicus appeared in 1913, with Herder in Freiburg as co-publishers, an atlas of the world church in folio-size with thirty-seven maps and texts in five languages. ${ }^{35}$ Here began a constant SVD tradition and leadership in Catholic atlas cartography over the course of the twenty-first century, until the sixth edition of the Atlas Hierarchicus in 2011. Jesuit cartography had been eclipsed.

élémentaires. They were printed in Lille by J. Lefort with several issues. The first editions are undated.

31 Atlas Geographicus Societatis Jesu. In quo delineantur quinque ejus modernae assistentiae, provinciae tres et viginti singularumque in toto orbe missiones (Paris: Georges Colombier, 1900).

32 J. Kleijntjens, Atlas der R. K. Missie in Nederlandsch Oost- en West-Indië (Maastricht: Van Aelst, 1928).

33 A study on the cartographic activities of the SVD is currently being prepared by the author.

34 Karl Streit, Katholischer Missionsatlas enthaltend die gesamten Missionsgebiete des Erdkreises (Steyl: Verlag der Missionsdruckerei Steyl, 1906). There was a parallel French edition Atlas des Missions catholiques contenant tous les territoires de missions de toute la terre.

35 Karl Streit, Atlas hierarchicus descriptio geographica et statistica S. Romanae Ecclesiae tum Occidentis tum Orientis juxta statum praesentem (Paderborn: Bonifatius-Druckerei; Freiburg: Herder, 1913). 
